\title{
Analisis Mutu Minyak Jelantah Hasil Peremajaan Menggunakan Tanah Diatomit Alami dan Terkalsinasi
}

\author{
${ }^{1}$ La Ode Sumarlin, ${ }^{2}$ Lela Mukmillah, ${ }^{2}$ Ratna Istianah \\ ${ }^{1)}$ Program Studi Kimia FST UIN Syarif Hidayatullah Jakarta \\ Jalan Ir. H. Juanda No 95 Ciputat Jakarta 15412 Indonesia \\ ${ }^{2)}$ Program Studi Kimia Universitas Muhammadiyah Sukabumi \\ e-mail : lamarid@yahoo.com
}

\begin{abstract}
Abstrak
Kualitas minyak goreng sangat ditentukan oleh sifat fisika dan kimianya. Semakin sering minyak goreng dipanaskan maka kualitasnya akan semakin menurun. Pada Penelitian ini dilakukan proses peremajaan minyak goreng bekas (minyak jelantah) dengan menggunakan dua adsorben, yaitu adsorben tanah diatomit alami dan tanah diatomit yang dikalsinasi. Dalam proses peremajaan ini dilakukan proses aktivasi terhadap adsorben untuk dapat meningkatkan daya serap adsorben terhadap minyak jelantah. Parameter uji yang dilakukan untuk mengetahui kualitas minyak jelantah hasil peremajaan oleh tanah diatomit terdiri atas kadar air, kadar kotoran, bilangan peroksida dan kadar asam dengan metode titrasi. Hasil penelitian menunjukkan bahwa minyak jelantah hasil peremajaan oleh tanah diatomit alami mengalami kenaikan kualitas. Hal ini ditunjukan oleh penurunan kadar air minyak jelantah yang semula $1,2412 \%$, kadar kotoran 3,2779\%, bilangan peroksida $0,0168 \mathrm{mg}$ $\mathrm{O}_{2} / 100 \mathrm{gr}$, dan bilangan asam sebesar 1,0037. Setelah diremajakan oleh tanah diatomit alami mengalami penurunan kadar air sebesar $0,6139 \%$, kadar kotoran 1,8100\%, bilangan peroksida $0,0121 \mathrm{mg} \mathrm{O}_{2} / 100 \mathrm{gr}$ dan bilangan asam sebesar 0,9751. Begitupun dengan minyak jelantah hasil peremajaan dengan adsorben tanah diatomit terkalsinasi dengan kadar air sebesar $0,2881 \%$ kadar kotoran $0,6429 \%$, bilangan peroksida $0,0099 \mathrm{mg} \mathrm{O}_{2} / 100 \mathrm{gr}$ dan bilangan asam sebesar 0,8038 . Minyak jelantah hasil peremajaan oleh tanah diatomit terkalsinasi mengalami peningkatan kualitas atau penurunan persentase kadar air sebesar 76,79\%, kadar kotoran 80,39\%, bilangan peroksida $41,07 \%$ dan bilangan asam sebesar $19,92 \%$. Begitupun untuk minyak jelantah hasil peremajaan oleh tanah diatomit alami. Namun kenaikan kualitasnya tidak sebesar hasil peremajaan oleh tanah diatomit terkalsinasi, persentase penurunan kadar air pada minyak hasil peremajaan tanah diatomit alami sebesar 50,54\% , kadar kotoran 44,78\%, bilangan peroksida 27,68\% dan bilangan asam sebesar $2,85 \%$. Dari data hasil penelitian dapat diketahui bahwa tanah diatomit alami daya serapnya lebih rendah daripada dengan tanah diatomit terkalsinasi.
\end{abstract}

Kata Kunci : Minyak jelantah, diatomit, kalsinasi, bilangan peroksida

\begin{abstract}
Frying oil quality is determined by physical and chemical characteristic. Frying oil is often boiled up so the temperature is less quality. The study was done, recycle oil bleaching process with two adsorbent, that were natural diatomite and calcined diatomite. The bleaching process was doing activation process to adsorbent, to increase its adsorption to recycle oil. Quality parameter of lipid and oil were water content, dirt content, peroxide value and acid value were determined by titrimetry. Result showed that recycle oil bleaching product by natural diatomite would increase quality. That were water content from recycle oil about $1,2412 \%$, dirt content about $3,2779 \%$, peroxide value about $0,0168 \mathrm{mg} \mathrm{O} / 100 \mathrm{gr}$ and the acid value about 1,0037 . Water content from recycle oil were bleached by natural diatomite about $0,6139 \%$, dirt content $1,8100 \%$, peroxide value about $0,0121 \mathrm{mg} \mathrm{O}_{2} / 100$ gr and the acid value about 0,9751 . That were water content from recycle oil about $0,2881 \%$, dirt content about $0,6429 \%$, peroxide value about $0,0099 \mathrm{mg} \mathrm{O}_{2} / 100 \mathrm{gr}$ and the acid value about 0,8038 . Recycle oil bleaching product by calcined diatomite would increase its quality. That were water content decreased about $76,79 \%$, dirt content about $80,39 \%$, peroxide value about $41,07 \%$ and the acid value about $19,92 \%$. Thus for that recycle oil bleaching product by natural diatomite. Although
\end{abstract}


increased its quality not better than calcined diatomite. The water content decreased about 50,54\%, dirt content decrease about $44,78 \%$, peroxide value about $27,68 \%$ and the acid value about $2,85 \%$. Based on data of research could recognized that natural diatomite its activated is lower than that calcined diatomite.

Keywords : Recycle oil, diatomite, calcination, peroxide value

\section{PENDAhUluan}

Kerusakan minyak akan mempengaruhi mutu dan nilai gizi bahan pangan yang digoreng. Minyak yang rusak akibat proses oksidasi dan polimerisasi akan menghasilkan bahan dengan cita rasa yang tidak enak (Budiarso,2004) serta kerusakan sebagian vitamin dan asam lemak esensial yang terdapat dalam minyak. Kerusakan minyak atau lemak akibat pemanasan suhu tinggi $\left(200-250^{\circ} \mathrm{C}\right)$ akan mengakibatkan keracunan dalam tubuh dan berbagai macam penyakit. Namun, kerusakan minyak juga dapat terjadi selama penyimpanan. Penyimpanan yang salah dalam jangka waktu tertentu dapat menyebabkan pecahnya ikatan trigliserida pada minyak yang pada akhirnya membentuk gliserol dan asam lemak bebas (Ketaren, 1986). Oleh karena itu diperlukan usaha untuk meningkatkan kualitas dan daya simpan minyak goreng. Salah satu upaya yang dilakukan adalah melalui proses peremajaan minyak jelantah (minyak bekas penggorengan).

Penelitian pengolahan minyak jelantah telah banyak dilakukan dan banyak juga yang menghasilkan temuan dalam bentuk paten. Proses pengolahan minyak jelantah telah dilakukan oleh Wulyoadi, dkk (2004), dimana minyak jelantah dimurnikan dengan membran. Hasil yang diperoleh menunjukkan bahwa minyak goreng jelantah hasil pemurnian mengalami penurunan bilangan asam dan bilangan peroksida, namun belum memenuhi persyaratan Standar Nasional Indonesia (SNI). Begitu pun penelitian yang dilakukan oleh Sumarni, dkk 2004, dengan menggunakan bentonit dan arang aktif untuk menjernihkan minyak jelantah. Hasil yang diperoleh untuk bilangan asam dan peroksida juga mengalami penurunan, namun belum memenuhi spesifikasi SNI. (Widayat dan Haryani, 2006). Pengolahan minyak jelantah dengan menggunakan membran, mempunyai kelemahan dalam biaya yang dibutuhkan besar dan umur membran tidak terlalu lama. Penggunaan karbon aktif untuk pengolahan juga mempunyai kelemahan karena memungkinkan tertinggalnya logam berat di dalam minyak goreng hasil. Logam berat seperti Zn umumnya digunakan sebagai aktivator pada pembuatan karbon aktif.

Oleh karena itu perlu secara terus menerus diupayakan berbagai alternatif adsorben yang dapat meremajakan minyak jelantah dari bahan yang murah dan aman. ini. Salah satu yang dapat diupayakan adalah penggunaan tanah diatomit sebagai adsorben. Tanah diatomit ini keberadaannya di Indonesia yang melimpah dan murah. Potensi endapan tanah diatomit yang cukup besar dan tersebar di berbagai daerah seperti Jawa Barat, Jawa Tengah dan Jawa Timur. Di daerah Jawa Barat endapan diatomit ditemukan di daerah Sukabumi, Kuningan, Garut, Bogor dan Tasikmalaya. Pada umumnya diatomit digunakan sebagai bahan pembersih minyak bakar, pelumas, minyak goreng, farmasi, kimia, kertas, keramik dan lainnya.

Untuk itu dalam penelitian ini akan dibandingkan tanah diatomit alami dan tanah diatomit yang telah dikalsinasi oleh pemanasan suhu $800^{\circ} \mathrm{C}$. Minyak jelantah yang digunakan adalah minyak bekas penggorengan tahu Sumedang. Parameter yang akan dilihat adalah parameter syarat mutu minyak goreng diantaranya Kadar air, Kadar kotoran, Bilangan peroksida, dan Bilangan asam.

Diharapkan penelitian ini adalah untuk memperoleh informasi sampai sejauh mana efektifitas meremajaan minyak jelantah dengan menggunakan adsorben tanah diatomit alami dan tanah diatomit kalsinasi.

\section{METODE PENELITIAN}

\section{Bahan dan Alat}

Bahan yang digunakan dalam penelitian ini adalah tanah diatomit dari Desa Kawah Manuk Kecamatan Darma Kuningan dan minyak goreng jelantah yang berasal dari penggorengan tahu Sumedang, kalium hidroksida, KI, $\mathrm{Na}_{2} \mathrm{SO}_{4}$, 
larutan kanji dan akuades untuk uji mutu minyak. Sedangkan alat-alat yang digunakan untuk penelitian ini adalah peralatan gelas pada umumnya, neraca analitik, buret, pengaduk magnetik, pompa vakum, dan tanur sedangkan alat instrumen yang digunakan untuk analisa adalah Atomic Absorption Spectrofotometry (AAS).

\section{Prosedur Kerja}

Secara garis besar penelitian ini dibagi ke dalam tiga tahap yaitu preparasi dan kalsinasi tanah diatomit, karaktristik tanah diatomit dan uji mutu minyak goreng.

\section{Preparasi dan Kalsinasi tanah Diatomit}

Tanah Diatomit yang digunakan pada penelitian ini dibagi kedalam 2 jenis yaitu tanah diatomit alami dan tanah diatomit hasil kalsinasi pada suhu $800^{\circ} \mathrm{C}$.

\section{Karakteristik Tanah Diatomit}

Contoh Tanah diatomit yang digunakan sebagai bahan adsorben peremajaan minyak jelantah diperiksa komposisi kimianya. Unsur dan senyawa yang diperiksa adalah : $\mathrm{SiO}_{2}$, $\mathrm{Al}_{2} \mathrm{O}_{3}, \mathrm{Fe}_{2} \mathrm{O}_{3}, \mathrm{CaO}, \mathrm{MgO}, \mathrm{K}_{2} \mathrm{O}, \mathrm{Na}_{2} \mathrm{O}$, hilang pijar / loss on ignition (LOI).

Pelarutan bantuan dengan peleburan $\mathrm{LiBO}_{2}$ anhidrat dalam cawan platina pada suhu 900-950 ${ }^{\circ}$. Selanjutnya dilarutkan dengan $\mathrm{HNO}_{3}$ $1: 24$ :

Sebanyak 0,2 gr contoh ditimbang dan dimasukkan ke dalam cawan platina yang berisi $\pm 1 \mathrm{gr} \mathrm{LiBO}_{2}$ anhidrat, diaduk sampai homogen. Setelah itu dimasukkan ke dalam tanur pada suhu $900-950^{\circ} \mathrm{C}$ selama \pm 15 menit atau sampai lebur sempurna (lelehan jernih) lalu didinginkan. Bagian luar cawan dibilas dengan air suling lalu dimasukkan ke dalam piala teflon.

Kemudian ditambahkan $\pm 50 \mathrm{~mL} \mathrm{HNO}_{3}$ $1: 24$ dan batang pengaduk magnet dimasukkan. Piala ditutup dengan kaca arloji, diaduk dengan pengaduk magnet sampai larutan sempurna. Hasil pelarutan dimasukkan ke dalam labu ukur $100 \mathrm{~mL}$, sedangkan piala teflon, batang pengaduk magnet, dan cawan platina dibilas dengan $\mathrm{HNO}_{3} 1$ : 24 sampai bersih. Larutan dalam labu ukur ditandabataskan dengan $\mathrm{HNO}_{3}$
1 : 24 dan dikocok sampai homogen (larutan utama).

a) Penentuan $\mathrm{SiO}_{2}$

Prinsip :

Larutan hasil peleburan ditambahkan asam dan diuapkan. Silikat yang tidak larut dipisahkan melalui penyaringan. Dengan penambahan $\mathrm{HF}$, maka $\mathrm{SiO}_{2}$ akan membentuk $\mathrm{SiF}_{4}$ yang menguap pada saat pemijaran. Kadar $\mathrm{SiO}_{2}$ dapat dihitung dari selisih berat yang hilang pada saat pemijaran.

Reaksi :

$\begin{array}{ll}\mathrm{SiO}_{2}+6 \mathrm{HF} & \longrightarrow \mathrm{SiF}_{4}+ \\ \mathrm{H}_{2} \mathrm{SiF}_{6} \longrightarrow 2 \mathrm{HF}\end{array}$

Sebanyak $50 \mathrm{~mL}$ larutan utama dimasukkan ke dalam gelas piala $250 \mathrm{~mL}$. Lalu ditambahkan 5-10 mL $\mathrm{H}_{2} \mathrm{SO}_{4} 1$ : 1 dan diuapkan sampai kering. Kemudian ditambahkan $50 \mathrm{~mL}$ air suling, disaring dengan kertas saring Whatman No. 40 dan dicuci dengan air suling panas sampai bersih.

Endapan dan kertas saring dipijarkan, diabukan dalam cawan platina, didinginkan lalu ditimbang (a gram). Abu dalam cawan dibasahi dengan air suling, dan ditambahkan HF secukupnya. Diuapkan sampai kering, didinginkan dan ditimbang (b gram).

Perhitungan :

Kadar $\mathrm{SiO}_{2}(\%)=\frac{(a-b) \mathrm{gr}}{\text { Berat contoh }(\mathrm{gr})} \times 100 \%$

b) Penentuan $\mathrm{Al}_{2} \mathrm{O}_{3}, \mathrm{Fe}_{2} \mathrm{O}_{3}, \mathrm{CaO}, \mathrm{MgO}$.

Prinsip :

Logam-logam oksida yang terdapat dalam larutan diperiksa dengan adsorbannya dengan Spektrofotometer Serapan Atom (SSA/AAS).

Contoh dari larutan utama dimasukkan ke dalam labu ukur dengan pengenceran seperlunya (20 kali dan 5 kali). Ditambahkan $10 \mathrm{~mL}$ larutan $\mathrm{Sr}^{3+} 3 \%$ dan 15 mL larutan $\mathrm{Li}^{+}$untuk $100 \mathrm{~mL}$ larutan sampai tanda tera dan dikocok sampai homogen. Kemudian diperiksa absorben contoh dan standar dengan menggunakan SSA pada kondisi yang sesuai tiap unsur.

Perhitungan :

Kadar unsur $(\%)=\underline{\text { Fp } x \text { ppm contoh } \times V} \times 100 \%$ 
Keterangan : $\mathrm{Fp}=$ faktor pengenceran

$\mathrm{V}=$ volume labu asal $(\mathrm{mL})$

c) Penentuan LOI (Loss on Ignition)

Prinsip :

Senyawa organik atau anorganik tertentu akan berkurang/hilang bila dipijarkan. Dengan menimbang contoh sebelum dan sesudah pemijaran maka kadar zat hilang pijar (LOI) dapat diketahui.

Sebanyak \pm 1 gr contoh ditimbang dalam cawan porselen yang telah diketahui beratnya (a gram). Lalu diimasukkan ke dalam tanur pada suhu $900-950^{\circ} \mathrm{C}$ selama 1 1,5 jam. Setelah tiu didinginkan dan ditimbang (b gram).

Perhitungan :

Kadar LOI $(\%)=\frac{(a-b) g r}{\text { Berat contoh }(g r)} \times 100 \%$

\section{Pengaruh suhu kalsinasi diatomit terhadap efisiensi peremajaan minyak jelantah.}

a) Aktivasi Diatomit

Membuat larutan asam klorida $0.1 \mathrm{~N}$ kemudian memasukkan 100 gram diatomit ke dalam gelas piala $100 \mathrm{ml}$ selanjutnya larutan asam klorida tersebut dimasukkan ke dalam gelas piala yang berisi diatomit sampai semuanya larut kemudian dikeringkan dengan oven pada suhu $105^{\circ} \mathrm{C}$.

b) Penyaringan Minyak Jelantah $500 \mathrm{ml}$ minyak jelantah ditambahkan ke dalam 5 gr diatomit alami yang diaktivasi tersebut kemudian diaduk selama $1 / 2-1$ jam, setelah itu suspensi tersebut disaring melalui filter kasar, lalu disaring lagi melalui filter halus dengan kertas saring Whatman 41. Penyaringan dilakukan dengan menggunakan pompa vakum.

Langkah yang sama dilakukan terhadap diatomit kalsinasi pada suhu $800^{\circ} \mathrm{C}$.

\section{Analisis Uji Mutu Minyak Goreng}

Minyak goreng jelantah sebelum dan sesudah dikontakkan dengan tanah diatomit dilakukan analisa syarat mutu minyak goreng meliputi : Penentuan Kadar air, Kadar kotoran, Bilangan peroksida, Bilangan asam.

\section{HASIL DAN PEMBAHASAN}

Sifat Tanah Diatomit

Tanah diatomit murni mengandung 97\% $\mathrm{SiO}_{2}$ yaitu silika dari cangkang diatomit dan selebihnya air. Namun kandungan sebanyak itu jarng ditemukan pada tanah diatomit yang terdapat di alam.

Tanah diatomit mempunyai berat jenis rendah $( \pm 0,45)$ oleh sebab itu agar tanah diatomit yang mati dapat membentuk endapan maka pengaruh arus listrik harus kecil. Daya serap air tanah diatomit 25 - 45\%, warna putih coklat tergantung kontaminasinya, kemampuan daya hantar listrik atau panas rendah.

Biasanya tanah diatomit akan bereaksi dengan alkali kuat dan asam HF, tetapi tidak dapat bereaksi dengan asam lainnya. Silikon dioksida yang terkandung didalamnya memiliki struktur yang unik, hasil pembentukan cangkang diatom. Pengotor yang sering ditemukan bercampur dengan diatomit, contohnya adalah fosil mikro organik, pasir tanah liat, kalsium karbonat, garam-garam terlarut dan bahan organik. Jenis dan jumlah pengotor yang ada tergantung pada kondisi pengendapan saat tanah diatomit mengendap.

Kelembaban tanah diatomit kasar mengandung $15-40 \%$ kelembaban. Selain air, banyak juga terkandung unsur-unsur lain seperti besi, kalsium, dan alumunium.

Tanah diatomit murni berwarna putih atau keputihan-putihan tetapi pengotornya berwarna agak gelap dengan nilai indeks bias berkisar dari 1,41 sampai 1,48. Densitas semu (apparent density) dari tanah diatomit serbuk berkisar mulai dari $7 \mathrm{lb} . \mathrm{ft}^{-3}$ sampai $20 \mathrm{lb} \mathrm{ft}^{-3}$ dan untuk padatan tidak murni 60lb. $\mathrm{ft}^{-3}$. Kelembaban tanah diatomit bisa lebih dari $65 \%$ tetapi dalam kondisi kering bisa mencapai 15 sampai $25 \%$. Konduktivitas thermal tanah diatomit rendah tetapi akan bertambah dengan bertambahnya persen pengotor. Titik lebur tanah diatomit bergantung pada kemurniannya, tetapi untuk tanah diatomit murni rata-rata sekitar $1590^{\circ} \mathrm{C}$ $\left(2900^{\circ} \mathrm{F}\right)$. (Mukmilah \& Saripah, 2001).

Penelitian ini bertujuan untuk mengetahui mutu minyak jelantah setelah dilakukan proses peremajaan dengan menggunakan adsorben tanah diatomit. Namun 
sebelum proses peremajaan minyak jelantah oleh tanah diatomit, terlebih dahulu dilakukan analisa komposisi kimia terhadap bahan adsorben.

Tabel 1. Komposisi Kimia Tanah Diatomit Sebelum Kalsinasi

\begin{tabular}{|c|c|}
\hline Komponen & Kandungan, \% Berat \\
\hline $\mathrm{SiO}_{2}$ & 54,9 \\
\hline $\mathrm{Al}_{2} \mathrm{O}_{3}$ & 16,67 \\
\hline $\mathrm{Fe}_{2} \mathrm{O}_{3}$ & 8,74 \\
\hline $\mathrm{CaO}$ & 0,14 \\
\hline $\mathrm{MgO}$ & 0,17 \\
\hline $\mathrm{LOI}$ & 11,40 \\
\hline $\mathrm{H}_{2} \mathrm{O}$ & 16,07 \\
\hline
\end{tabular}

Hasil analisa tanah diatomit yang dilaksanakan di Pusat Penelitian dan Pengembangan Teknologi Mineral (PPTM) dapat dilihat pada tabel 1. Sedangkan hasil analisa komposisi kimia tanah diatomit setelah dikalsinasi dapat dilihat pada tabel 2 .

Tabel 2. Hasil analisa komposisi tanah diatomit setelah kalsinasi

\begin{tabular}{|c|c|}
\hline Komponen & $\begin{array}{c}\text { Kandungan, \% } \\
\text { Berat }\end{array}$ \\
\hline $\mathrm{SiO}_{2}$ & 62,0 \\
\hline $\mathrm{Al}_{2} \mathrm{O}_{3}$ & 18,91 \\
\hline $\mathrm{Fe}_{2} \mathrm{O}_{3}$ & 8,69 \\
\hline $\mathrm{CaO}$ & 0,15 \\
\hline $\mathrm{MgO}$ & 0,17 \\
\hline $\mathrm{LOI}$ & 2,08 \\
\hline $\mathrm{H}_{2} \mathrm{O}$ & 2,01 \\
\hline
\end{tabular}

Untuk memperoleh data kualitas mutu minyak jelantah hasil peremajaan oleh adsorben tanah diatomit, maka dilakukan perlakuan dengan 2 variabel, yaitu : tanah diatomit alami tanpa kalsinasi dan tanah diatomit kalsinasi. Adapun mutu minyak jelantah hasil peremajaan oleh tanah diatomit disajikan pada tabel 3.

Dari hasil analisa komposisi kimia menggunakan metode SNI 13-3608-1994 (BSN,2004) yaitu dengan metode peleburan tanah diatomit dengan litium metaborat, dapat dilihat bahwa kandungan $\mathrm{SiO}_{2}$ sebelum kalsinasi sebesar $54,9 \%$ dan setelah kalsinasi mengalami kenaikan menjadi 62,0\%. Kenaikan kadar $\mathrm{SiO}_{2}$ ini disebabkan karena bahan organik dalam tanah diatomit habis terbakar pada saat kalsinasi.

Tabel 3. Mutu Minyak Jelantah dari ketiga contoh yang diuji

\begin{tabular}{|c|c|c|c|}
\hline Jenis minyak & $\begin{array}{c}\text { Minyak } \\
\text { Jelantah } \\
(\mathrm{MJ})\end{array}$ & $\begin{array}{c}\text { Minyak } \\
\text { Hasil } \\
\text { Peremajaan } \\
\text { Diatomit } \\
\text { Alami } \\
\text { (MJDA) }\end{array}$ & $\begin{array}{c}\text { Minyak } \\
\text { Hasil } \\
\text { Peremajaan } \\
\text { Diatomit } \\
\text { terkalsinasi } \\
\text { (MJDK) }\end{array}$ \\
\hline $\begin{array}{c}\text { Kadar Air } \\
(\%)\end{array}$ & 1,2412 & 0,6139 & 0,2881 \\
\hline $\begin{array}{c}\text { Kadar kotoran } \\
(\%)\end{array}$ & 3,2779 & 1,8100 & 0,6429 \\
\hline $\begin{array}{c}\text { Bilangan } \\
\text { peroksida } \\
\text { (mg O } / 100 \mathrm{~g})\end{array}$ & 0,0168 & 0,0121 & 0,0099 \\
\hline $\begin{array}{c}\text { Bilangan } \\
\text { Asam }\end{array}$ & 1,0037 & 0,9751 & 0,8038 \\
\hline \multicolumn{2}{|c|}{} & & \\
\hline
\end{tabular}

Menurut Adamson (1980) dalam Vitaria (2007), Kalsinasi merupakan proses aktivasi secara pemanasan yang berfungsi untuk menambah daya serap suatu zat adsorben (pengadsorpsi).

Sesuai dengan sifat dari tanah diatomit yang mempunyai kemampuan untuk menyerap sejumlah molekul yang terdapat dalam larutan, maka untuk menambah daya serapnya dilakukan aktivasi secara fisika dan kimia. Pada penelitian ini dilakukan aktivasi secara fisika yaitu berupa pemanasan dengan tujuan menghilangkan molekul air yang terdapat dalam poripori/rongga permukaan tanah diatomit.

Tanah diatomit sebelum ataupun setelah dikalsinasi tersebut selanjutnya digunakan pada proses peremajaan minyak jelantah yang berfungsi sebagai adsorben untuk minyak jelantahnya.

Pendapat tentang mekanisme adsorbsi zat warna pada proses pemucatan minyak kelapa sawit masih terdapat kesimpang siuran, sebagian pendapat bahwa gejala tersebut adalah peristiwa kimia dan yang lain menyatakan hal itu adalah peristiwa fisika, akan tetapi disimpulkan sebagai affinitas permukaan terhadap substrat.

Pada adsorbsi fisika terjadi proses cepat dan setimbang (reversible) sedangkan adsorbsi kimia berlangsung lamban tetapi ireversibel. Perbedaan antara adsorbsi kimia dengan adsorbsi 
fisika kadang-kadang tidak jelas dan banyak prinsip-prinsip adsorbsi fisika berlaku juga pada adsorbsi kimia.

Gaya-gaya yang terlibat pada proses adsorbsi antara lain gaya tarik Van der Walls yang non polar, pembentukan ion hidrogen, gaya penukaran ion dan pembentukan ikatan kovalen (Pasaribu, 2004).

\section{Kadar Air}

Berdasarkan Standar Nasional Indonesia SNI 01-3741-2002 minyak goreng yang bermutu baik harus mengandung kadar air maksimum 0,3\% (Dirjen Perkebunan, 1989). Air adalah konstituen yang keberadaannya dalam minyak sangat tidak diinginkan karena akan menghidrolisis minyak menghasilkan asam-asam lemak bebas yang menyebabkan bau tengik pada minyak (Poedjiadi, 1999).

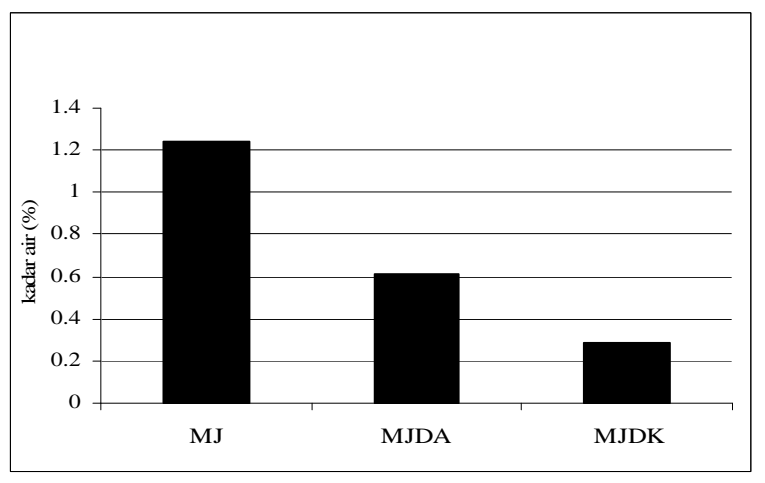

Gambar 1. Grafik Kadar Air dalam minyak jelantah yang diuji

Berdasarkan data yang ada pada gambar 1 kadar air minyak jelantah (MJ) lebih tinggi dibandingkan dengan kadar air minyak jelantah hasil peremajaan menggunakan adsorben tanah diatomit (MJDA dan MJDK), yang berarti minyak jelantah yang diremajakan dengan adsorben tanah diatomit memiliki jumlah air yang berkurang. Kadar air minyak jelantah hasil peremajaan oleh tanah diatomit terkalsinasi lebih besar persentase penurunannya daripada menggunakan adsorben tanah diatomit alami. Hal ini menunjukan bahwa proses kalsinasi mampu menghilangkan molekul air dari dalam rongga permukaan / pori-pori diatomit, sehingga menyebabkan tanah diatomit berinteraksi secara efektif dengan adsorbat.
Ukuran pori-pori cukup penting berperan dalam proses adsorpsi. Menurut Smith (1992) dalam Vitaria (2007), molekul dengan ukuran besar sulit untuk masuk ke dalam pori atau rongga-rongga yang terdapat dalam adsorben jika ukuran porinya lebih kecil dibanding molekulnya. Faktor-faktor yang mempengaruhi kapasitas adsorpsi diantaranya yaitu luas area permukaan, ukuran pori-pori, kelarutan adsorbat, $\mathrm{pH}$ dan suhu.

Adsorben tanah diatomit alami mampu mengurangi kadar air pada minyak jelantah sebesar 50,54 \% sedangkan tanah diatomit terkalsinasi dapat menurunkan kadar air pada minyak jelantah sampai 76,79\%.

Kadar air sebesar 0,2881\% telah memenuhi persyaratan SNI. Standar mutu minyak goreng menurut SNI-01-3741-2002 pada rentang $0,1-0,3 \%$.

\section{Kadar Kotoran}

Minyak yang bermutu baik mensyaratkan kadar kotoran maksimal 0,3\% (SNI 01-3741-2002). Kadar kotoran yang terdapat pada minyak dapat menurunkan kualitas minyak karena dapat mempengaruhi rasa, bau, dan warna pada bahan pangan yang digoreng. Oleh karena itu minyak harus dihindarkan dari kandungan kotoran yang besar (> 0,3\%) agar kondisi mutunya tetap terjaga.

Berikut ini adalah gambar 2 yang berisi tentang grafik jumlah kotoran yang tekandung pada ketiga jenis minyak jelantah yang diuji.

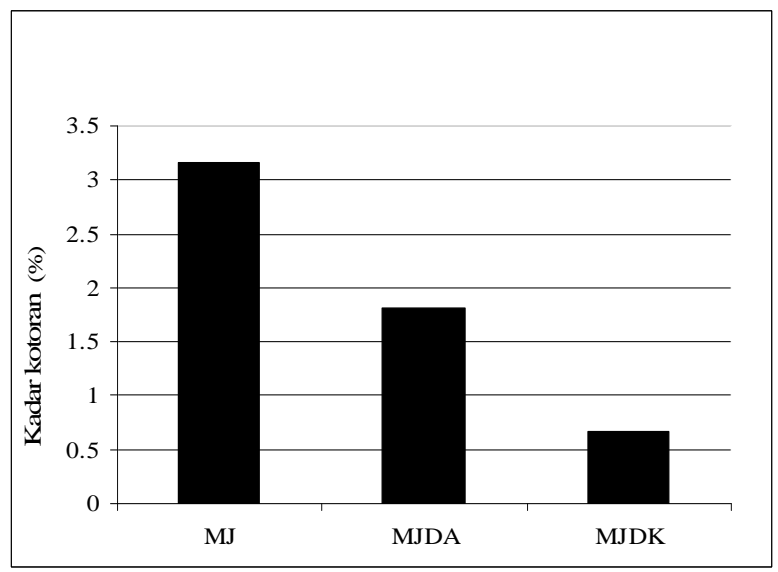

Gambar 2. Grafik Kadar kotoran dalam minyak jelantah yang diuji 
Pada gambar 2 terlihat bahwa minyak jelantah hasil peremajaan oleh tanah diatomit (MJDA dan MJDK), memiliki kadar kotoran lebih rendah dibandingkan dengan minyak jelantah tanpa perlakuan (MJ). Hal ini menunjukan telah terjadi penurunan jumlah kotoran dalam minyak jelantah setelah diremajakan oleh tanah diatomit. Penurunan jumlah kotoran terlihat lebih besar selisihnya pada minyak jelantah (MJ) dengan minyak jelantah hasil peremajaan oleh tanah diatomit yang dikasinasi (MJDK).

Tampak bahwa tanah diatomit hasil kalsinasi mampu menyerap partikel-partikel pengotor pada minyak jelantah $80,39 \%$ jauh lebih banyak daripada yang dapat diserap oleh adsorben tanah diatomit alami sebesar $44,78 \%$. Hal ini menunjukkan bahwa proses kalsinasi pada tanah diatomit dapat mempengaruhi pengurangan jumlah kotoran dan sesuai dengan data uji pendahuluan pada tanah diatomit bahwa proses kalsinasi dapat mengurangi kadar kotoran yang terkandung dalam tanah diatomit tersebut.

\section{Bilangan Peroksida}

Bilangan peroksida adalah banyaknya miliekivalen oksigen aktif yang terdapat dalam 1000 gram minyak atau lemak (Apriantono, 1989). Bilangan peroksida merupakan nilai terpenting untuk mengetahui tingkat kerusakan yang telah terjadi pada minyak atau lemak yang diakibatkan oleh proses oksidasi yang berlangsung bila terjadi kontak antara oksigen dengan minyak. Asam lemak tidak jenuh penyusun suatu trigliserida dapat mengikat oksigen pada ikatan rangkapnya, sehingga membentuk peroksida (Kataren, 1986). Makin besar bilangan peroksida menunjukkan makin besar pula derajat kerusakan pada minyak.

Syarat mutu bilangan peroksida pada minyak goreng menurut SNI.01-3741-2002 (Dirjen Perkebunan, 1989) maksimal sebesar 1 $\mathrm{mg} \mathrm{O}_{2} / 100 \mathrm{~g}$ minyak. Bilangan peroksida diatas $1 \mathrm{mg} \mathrm{O}_{2} / 100 \mathrm{~g}$ minyak akan menunjukkan mutu minyak yang buruk. Dari hasil penelitian dapat dilihat pada gambar 4.3 diperoleh bilangan peroksida Minyak jelantah (MJ) sebesar 0,0168 $\mathrm{mg} \mathrm{O}_{2} / 100 \mathrm{~g}$, MJDA sebesar 0,0121 $\mathrm{mg} \mathrm{O}_{2} /$ $100 \mathrm{~g}$ serta MJDK 0,0099 mg O $/ 100 \mathrm{~g}$. Oleh karena itu, dilihat dari salah satu persyaratan mutu untuk minyak goreng yaitu bilangan peroksidanya yang harus di bawah $1 \mathrm{mg} \mathrm{O}_{2} / 100$ g minyak, baik minyak jelantah (MJ) ataupun minyak jelantah hasil peremajaan menggunakan adsorben tanah diatomit ( MJDA dan MJDK) memiliki bilangan peroksida yang jauh di bawah harga $1 \mathrm{mg} \mathrm{O} / 100 \mathrm{~g}$ minyak. Minyak jelantah yang telah diremajakan oleh adsorben tanah diatomit hasil kalsinasi memiliki bilangan peroksida yang paling rendah dibandingkan dengan adsorben tanah diatomit alami, hal ini menunjukkan bahwa MJDK memiliki kemampuan lebih besar untuk menghilangkan senyawa hasil oksidasi minyak berupa hidroperoksida dan peroksida.

Minyak akan teroksidasi bila minyak mengalami kontak dengan sejumlah oksigen. Oksidasi minyak umumnya akan berlangsung melalui mekanisme reaksi radikal bebas yang melibatkan tiga tahap reaksi yaitu inisiasi, propagasi, dan terminasi. Radikal-radikal bebas awal, juga hidroperoksida dan peroksida, akan terbentuk pada tahap inisiasi. Terjadinya reaksi rantai radikal-radikal bebas sehingga membentuk radikal-radikal bebas baru disebut tahap propagasi. Reaksi yang terjadi pada tahap propagasi akan dihentikan oleh tahap terminasi. Pada tahap ini radikal bebas yang satu akan bergabung dengan radikal bebas yang lainnya membentuk senyawa stabil. Kenaikan harga bilangan peroksida merupakan indikator bertambahnya jumlah peroksida dan peroksida yang terbentuk dalam minyak dan sebagai peringatan bahwa sebentar lagi minyak akan bau tengik.

Pada gambar 3 dapat dilihat bahwa MJDA dan MJDK memiliki bilangan peroksida yang lebih kecil dibandingkan dengan MJ (minyak jelantah). Hal ini menunjukkan telah terjadi penurunan konsentrasi hidroperoksida atau peroksida dalam minyak jelantah setelah minyak jelantah tersebut diremajakan oleh tanah diatomit. Tanah diatomit ini dapat mengadsorpsi partikel-partikel hidroperoksida dan peroksida dari dalam minyak jelantah sehingga mengurangi jumlahnya dalam minyak jelantah. Tanah diatomit alami dapat menurunkan bilangan peroksida minyak jelantah sebesar $27,68 \%$ sedangkan adsorben tanah diatomit terkalsinasi mampu menurunkan bilangan peroksida sampai $41,07 \%$. 


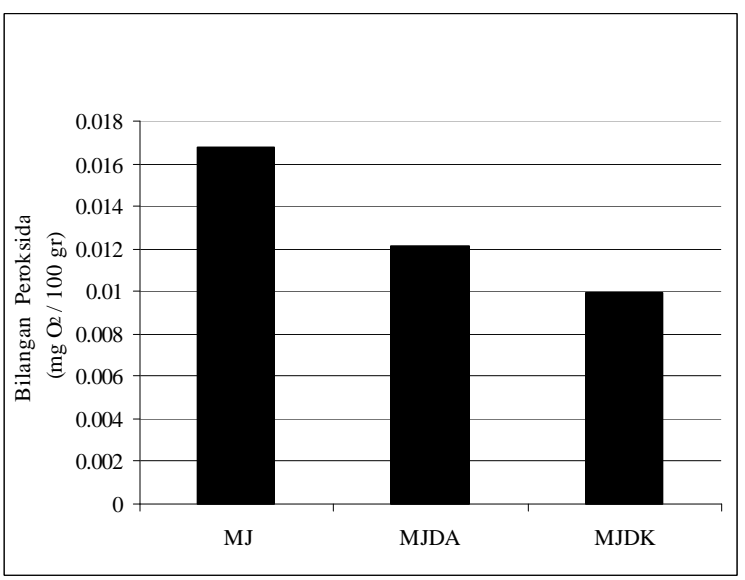

Gambar 3. GrafikBilangan Peroksida dalam minyak jelantah yang diuji

Persentase angka penurunan ini lebih kecil dibandingkan dengan penelitian terdahulu yang dilakukan oleh Wahjuni, dkk 2008. Peremajaan minyak goreng dengan adsorben Arang sekam padi IR 64 yang diaktifkan oleh kalium hidroksida dapat menurunkan bilangan peroksida sebesar $84,4 \%$ dari angka peroksida $0,308 \mathrm{mg} \mathrm{O}_{2} / 100$ gr menjadi $0,048 \mathrm{mg} \mathrm{O}_{2} / 100$ gr.

\section{Bilangan Asam (Acid Value)}

Bilangan asam digunakan untuk mengukur jumlah asam lemak bebas yang terdapat dalam minyak dihitung berdasarkan berat molekul dari asam lemak atau campuran asam lemak. Bilangan asam dinyatakan sebagai jumlah miligram $\mathrm{KOH} 0,1 \mathrm{~N}$ yang digunakan untuk menetralkan asam lemak bebas yang terdapat dalam 1 gram minyak atau lemak.

Jumlah asam lemak bebas yang terdapat dalam minyak dapat menunjukkan kualitas minyak, dimana semakin tinggi nilai asam lemak bebas maka semakin turun kualitas. Adanya asam lemak bebas pada minyak disebabkan karena minyak mengalami proses hidrolisis. Hidrolisis trigliserida dalam minyak akan menghasilkan komponen asam lemak dan monogliserida. Pada tahap akhir akan menghasilkan gliserol dan asam lemak. (Wnarno, 2004). Konstituen yang dapat menghidrolisis minyak diantaranya yaitu air dan enzim. Tingkat hidrolisis minyak yang tinggi akan menyebabkan tingginya kadar asam lemak bebas minyak. Tingkat hidrolisis minyak yang tinggi tersebut disebabkan oleh besarnya jumlah konstituen penghidrolisis minyak, yaitu jumlah air yang cukup tinggi atau tingginya aktivitas enzime lipase dalam minyak. Oksidasi komponen-komponen minyak atsiri terutama golongan aldehid dapat membentuk gugus asam karboksilat sehingga akan menambah nilai bilangan asam suatu lemak atau minyak (Feryanto, 2007)

Menurut Griswold (1962) di dalam Maslahat dkk (2004) stabilitas minyak goreng dipengaruhi oleh beberapa faktor, antara lain derajat ketidakjenuhan asam lemak yang dikandungnya, penyebaran ikatan rangkap dan bahan-bahan pembantu yang dapat mempercepat atau menghambat proses kerusakan. Bahan pembantu tersebut terdapat secara alami atau sengaja ditambahkan.

Berdasarkan data pada gambar 4 terjadi penurunan bilangan asam lemak bebas pada minyak jelantah yang tanpa perlakuan (MJ) dengan minyak jelantah dengan perlakuan (MJDA \& MJDK).

Tampak bahwa bilangan asam minyak jelantah yang telah dikalsinasi lebih rendah dibandingkan kedua jenis minyak lainnya. Hal ini menunjukkan kemampuan kedua jenis tanah diatomit tersebut yang dapat menyerap partikelpartikel asam lemak bebas sehingga minyak jelantah hasil peremajaannya memiliki bilangan asam yang berkurang. Namun kemampuannya untuk menghilangkan (melalui proses adsorpsi) partikel-partikel asam lemak bebas dari dalam minyak jelantah itu tidak besar dibandingkan penelitian terdahulu.

Menurut Winarno (1999), filtrasi minyak goreng bekas dengan tanah diatomit saja akan menghilangkan remah-remah makanan dalam minyak dan senyawa-senyawa yang mengkatalisis kerusakan minyak. yang terdapat Pada umumnya, adsorben dapat menghilangkan sebagian asam lemak bebas, komponen polar teroksidasi dan warna yang timbul dari reaksi pencoklatan non enzimatik. 


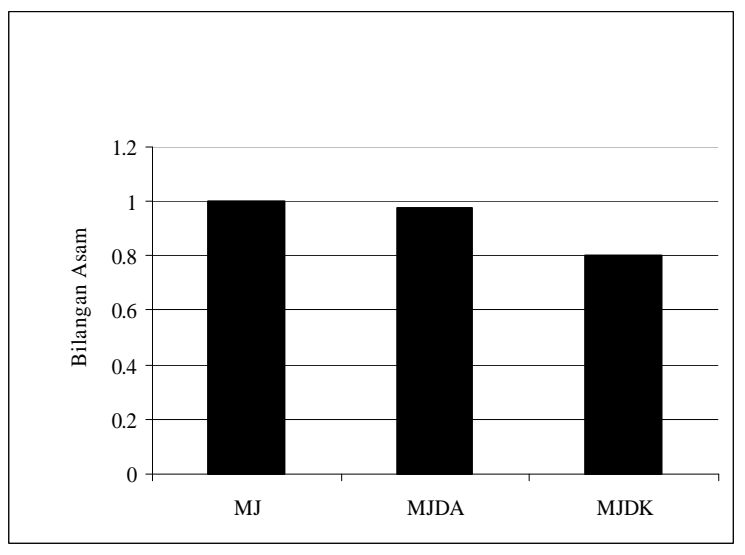

Gambar 4. Bilangan asam dalam minyak jelantah yang diuji

Penurunan bilangan asam minyak jelantah hasil peremajaan dengan adsorben tanah diatomit alami sebesar $2,85 \%$ sedangkan penurunan bilangan asam dengan adsorben tanah diatomit terkalsinasi sebesar $19,92 \%$.

Oleh karena itu, peremajaan dapat dikatakan tidak efektif untuk menghilangkan pengotor minyak jelantah berupa asam lemak bebas karena adsorben tanah diatomit hanya dapat menyerap sedikit pengotor tersebut. Dibandingkan dengan penelitian terdahulu yang dilakukan oleh Widayat dan Haryani, 2006, peremajaan minyak jelantah menggunakan adsorben zeolit alam diperoleh kondisi optimum pada berat zeolit 19,07 gram dan diameter zeolit 1,69 $\mathrm{m}$, memperoleh bilangan asam sebesar 1,71. Bilangan asam tersebut telah memenuhi SNI minyak goreng, dengan nilai mean square residual (selisih rata-rata kuadrat antara hasil pengamatan dan prediksi) sebesar 0,014 .

\section{KESIMPULAN DAN SARAN}

Beberapa hasil yang dapat disimpulkan dari proses peremajaan minyak jelantah dengan menggunakan adsorben tanah diatomit adalah sebagai berikut :

1. Hasil penelitian menunjukan bahwa minyak jelantah hasil peremajaan oleh tanah diatomit alami mengalami kenaikan kualitas. Hal ini ditunjukan oleh penurunan minyak jelantah yang semula memiliki kadar air sebesar 1,2412 \%, kadar kotoran 3,2779\%, bilangan peroksida $0,0168 \mathrm{mg} \mathrm{O}_{2} / 100 \mathrm{gr}$ dan bilangan asam sebesar 1,0037. Kadar air untuk minyak jelantah hasil peremajaan tanah diatomit alami sebesar $0,6139 \%$, kadar kotoran $1,8100 \%$, bilangan peroksida $0,0121 \mathrm{mg} \mathrm{O}_{2} / 100 \mathrm{gr}$ dan bilangan asam sebesar 0,9751. Begitupun dengan minyak jelantah hasil peremajaan dengan adsorben tanah diatomit terkalsinasi dengan kadar air sebesar 0,2881\% kadar kotoran 0,6429\%, bilangan peroksida $0,0099 \mathrm{mg} \mathrm{O}_{2} / 100 \mathrm{gr}$ dan bilangan asam sebesar 0,8038 .

2. Mutu minyak jelantah hasil peremajaan oleh tanah diatomit terkalsinasi mengalami kenaikan kualitas dan persentase penurunan lebih besar dari pada peremajaan menggunakan tanah diatomit alami. Persentase penurunan kadar air untuk minyak hasil peremajaan tanah diatomit alami sebesar $50,54 \%$, kadar kotoran $44,78 \%$, bilangan peroksida $27,68 \%$ dan bilangan asam sebesar 2,85\%. Sedangkan persentase penurunan kadar air pada minyak hasil peremajaan tanah diatomit terkalsinasi sebesar 76,79\% , kadar kotoran 80,39\%, bilangan peroksida $41,07 \%$ dan bilangan asam sebesar $19,92 \%$.

\section{Saran}

Perlu dilakukan penelitian lanjutan mengenai :

1. Pengujian kandungan kadar logam yang terdapat pada minyak hasil peremajaan oleh adsorben tanah diatomit karena memungkin tertinggalnya logam $(\mathrm{Fe}$ dan $\mathrm{Pb})$ di dalam minyak jelantah hasil peremajaan.

2. Analisis adsorben tanah diatomit setelah proses penyerapan minyak

\section{DAFTAR PUSTAKA}

1. Apriantono, A. Dkk. 1989. Analisis Pangan. Pusat Antar Universitas Pangan dan Gizi. IPB. Bogor

2. BSN. 2004. Badan Standarisasi Nasional. SNI Minyak Goreng. http://bsn.or.id/sni (diakses 21 Juli 2008)

3. BSN. 2006. Badan Standarisasi Nasional. SNI Minyak Kelapa Sawit Mentah (Crude Palm Oil). http://bsn.or.id/sni (diakses 21 Juli 2008) 
4. Budiarso, IT. 2004. Minyak kelapa dan urin obat alternatif untuk HIV/AIDS http://www.medikaholistik.com. 25 Agustus 2006.

5. Dirjen Perkebunan. 1989. Usaha Budidaya, pemanfaatan hasil, dan aspek pemasaran Kelapa Sawit. Penebar Swadaya. Jakarta

6. Feryanto. 2007. Essensial Oil Corner/Parameter Kualitas Minyak Atsiri. Akses pada 22 Desember 2007.

7. Ketaren, S. 1986. Pengantar Teknologi Minyak dan Lemak Pangan. Jakarta: UI-Press.

8. Maslahat, M ; M. Wahab dan Yuniasti. 2004. Uji Kualitas Fisiko Kimia Minyak Sawit Setelah Pemanasan Beberapa Kali. J. Nusa Kimia. Vol. 4 No.2: 39-56

9. Mukmilah, L.Y. \& Saripah, L. 2001. Kajian Awal Pembuatan Sodium Silikat Dari Tanah Diatomit. Bandung : UNJANI.

10. Pasaribu, N. 2004. Minyak Buah Kelapa Sawit. http://id.wikipedia.org/wiki/Kelapa_sawit (diakses 29 Juli 2008).

11. Poedjiadi, A. (1999). Dasar-Dasar Biokimia. Jakarta: UI-Press.

12. Vitara, Andhi. 2007. Pemerangkapan Ammonium $\left(\mathrm{NH}^{+}\right)$dari Urine dengan Zeolit pada berbagai Variasi Konsentrasi Urine. Sukabumi : UMMI

13. Widayat, S. dan K, Haryani. 2006. Optimasi Proses Adsorbsi Minyak Goreng Bekas dengan Adsorbent Zeolit Alam : Studi Pengurangan Bilangan Asam. J. Teknik Gelagar Vol. 17, No. 01, April $2006: 77-82$

14. Winarno, FG. 2004. Kimia Pangan dan Gizi. PT. Jakarta : Gramedia Pustaka Utama.

15. Winarno, FG. 1999. Minyak goreng Dalam Menu Masyarakat. Bogor : Pusat Pengembangan Teknologi Pangan IPB. 